Bu makaleye atıfta bulunmak için/To cite this article:

DEMIR, A. SAHINOĞLU, T. ERSUNGUR S. M. (2021). Makroekonomik Değiskenlerin Doğrudan Yabancl Yatırımlar Üzerine Etkisi: Türkiye Ekonomisi Açısından Değerlendirme. Atatürk Üniversitesi Sosyal Bilimler Enstitüsü Dergisi, 25 (4), 1396-1419

\title{
Makroekonomik Değișkenlerin Doğrudan Yabancı Yatırımlar Üzerine Etkisi: Türkiye Ekonomisi Açısından Değerlendirme
}

\author{
Ayhan DEMIR ${ }^{(*)}$ \\ Tuba ŞAHINOĞLU ${ }^{(* *)}$ \\ Şaban Mustafa ERSUNGUR ${ }^{(* * *)}$
}

Öz: Çalışmada makroekonomik değişkenlerden ekonomik büyüme, ithalat, ihracat, cari açık, enflasyon ve işsizliğin doğrudan yabancı yatırımlar üzerindeki etkileri 1980-2020 dönemi için Eşbütünleşme ve Granger Nedensellik Testi kullanılarak ele alınmıştır. Analiz sonucunda elde edilen bulgulara göre, çalışma kapsamında seçilen makroekonomik değişkenlerden enflasyon ile doğrudan yabancı yatırımlar arasında uzun dönemde çift yönlü nedensellik ilişkisi olduğu tespit edilmiştir. Diğer yandan ekonomik büyümeden doğrudan yabancı yatırımlara doğru tek yönlü bir nedensellik söz konusudur. Etki-Tepki Analizi sonucunda da benzer bulgular elde edilmiştir.

Anahtar Kelimeler: Doğrudan yabancı yatırımlar, makroekonomik değişkenler, Granger Nedensellik Analizi, etki tepki analizi.

JEL Kodlart: A10, C01, F10, F40.

\section{The Effect of Macroeconomic Variables on Foreign Direct Investments: An Evaluation in Terms of Turkish Economy}

Abstract: In the study, the effects of macroeconomic variables such as economic growth, imports, exports, current account deficit, inflation and unemployment on foreign direct investments are discussed using Cointegration and Granger Causality Tests for the 1980-2020 period. According to the findings obtained as a result of the analysis, it has been determined that there is a bidirectional causality relationship between inflation and foreign direct investments in the long run which are among the macroeconomic variables selected within the scope of the study. On the other hand, there is a unidirectional causality running from economic growth to foreign direct investments. Similar findings were obtained as a result of the Impact-Response Analysis.

Keywords: Foreign Direct Investments, macroeconomic variables, Granger Causality Analysis, impulse response analysis.

JEL Codes: A10, C01, F10, F40.

Makale Gelis Tarihi: 08.09.2021

Makale Kabul Tarihi: 25.12.2021

DOI: 10.53487/ataunisosbil.948184

\footnotetext{
*) Doktora Öğrencisi, Atatürk Üniversitesi Sosyal Bilimler Enstitüsü İktisat Anabilim Dalı (e-posta: ayhdemir@gmail.com) (D) ORCID ID. https://orcid.org/0000- 0002-2946-2546

$\left.{ }^{* *}\right)$ Dr. Öğr. Üyesi, Atatürk Üniversitesi İktisadi ve İdari Bilimler Fakültesi İktisat Bölümü (e-posta: tsahinoglu@atauni.edu.tr) (D) ORCID ID. https://orcid.org/0000- 0002-5742-247X ${ }^{* * * *)}$ Dr. Öğr. Üyesi, Atatürk Üniversitesi İktisadi ve İdari Bilimler Fakültesi İktisat Bölümü (e-posta: ersungur@atauni.edu.tr) (D ORCID ID. https://orcid.org/0000- 0003-3661-7216

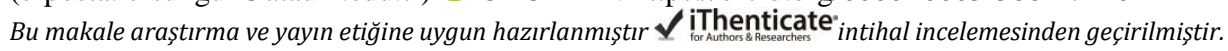




\section{Giriş}

Doğrudan yabancı yatırımlar (DYY), gelişmiş ve gelişmekte olan ülkelerin refahını artırmada büyük rol oynamasına karşın özellikle gelişmekte olan ülkeler için önemli bir dış finansman kaynağı olarak ön plana çıkmaktadır. Dolayısıyla bu ülkeler yabancı sermayeyi ülkelerine çekebilmek için yoğun rekabete girmekte ve sermaye girişini teşvik edici yönde politikalar izlemektedir. Diğer yandan bazı ülkeler bu konuda daha başarılı iken bazıları daha yetersiz kalmaktadır. Bu başarının arkasında ev sahibi ülkenin DYY konusundaki çabalarının yanı sıra enflasyon, ekonomik büyüme, ihracat ve ithalat gibi makroekonomik faktörlerin etkisi yer almaktadır.

DYY'ların görünümüne bakıldığında; pandemi ve devamında yaşanan arz kesintileri, talep daralmaları ve ekonomik aktörlerin karamsar görünümünün bir sonucu olarak 2020'nin ilk yarısında küresel DYY akışlarının 2020 yılının ilk çeyreğinde \%41 düşüşle 227 milyar dolar ve 2 . çeyreğinde ise \%39 düşüşle 137 milyar dolar olarak gerçekleştiği görülmektedir. $\mathrm{Bu}$ rakamlar 2019'un ilk yarısına kıyasla küresel doğrudan yabancı yatırım akışlarında \%38'lik bir düşüş yaşandığı anlamına gelmektedir (OECD, 2020). Diğer yandan yapısal olarak zayıf ve kırılgan ekonomilerde DYY'nin görünümünün daha olumsuz olduğu görülmektedir (UNCTAD, 2020).

Ülkelerin kalkınmasında ve refah sevilerinin yükselmesinde etkili olan DYY girişleri, ev sahibi ülkelerin finansman problemlerinin giderilmesinde de büyük rol oynamaktadır. Dolayısıyla, ülkelerin büyüme süreçlerindeki etkisinden dolayı DYY'lere olan ilgi ile birlikte, makroekonomik değişkenlerin DYY'ler üzerindeki etkisinin neler olduğu araştırılmaya başlamıştır. Çünkü yabancı sermaye girişi ile ekonomik istikrar arasında doğru orantılı bir ilişki olduğu, yapılan ulusal ve uluslararası çalışmaların bulgularından görülmektedir (Kurt, 2018; Aytekin, 2019). Yabancı yatırımcılar, yatırım kararları alırken ülkelerin hukuki, politik ve ekonomik risklerini göz önünde bulundurmaktadır. Zira doğrudan yabancı yatırımların uzun vadeli yapısı nedeniyle ekonomik kriz veya ülkenin yatırım koşullarını etkileyen diğer olumsuz gelişmeler durumunda anında ülkeyi terk etmesi zordur. Bu nedenle yabancı yatırımcılar bir ülkeye yatırım yaptıklarında o ülkenin potansiyel risklerini üstlenmektedir. Ampirik literatürde bir ülkenin risk düzeyi ne kadar yüksekse (hem ekonomik hem de politik), o ülkeye DYY girişinin o kadar azaldığı yönünde kanıtlar güçlüdür (Kanlı ve Aydoğuş, 2017).

Bu ülkeler için doğrudan yabancı yatırımların diğer dış finansman kaynaklarına göre daha avantajlı olduğu düşünülmektedir. Ülkede ekonomik kriz veya olağanüstü başka süreçlerin oluşması durumunda doğrudan yabancı yatırımlar ülkeyi hemen terk edemezler. Ayrıca, doğrudan yabancı yatırımların ülkeye teknoloji transferi sağlama, beşeri sermayeyi güçlendirme gibi olumlu başka etkiler yaratma potansiyeli de bulunmaktadir.

Dolayısıyla özellikle gelişmekte olan ülkelerin büyüme süreçlerindeki katkısı nedeniyle DYY'lerin ülkeye girişinin artırılması amacıyla izlenecek politikalar açısından DYY girişi üzerinde etkili olan unsurların değerlendirilmesi önem taşımaktadır. Gelişmekte olan ülkeler arasında yer alan Türkiye son yıllarda yabancı sermaye girişi yüksek olan ülkeler arasında olması nedeniyle DYY'larını ülkeye çekme konusundaki 
Makroekonomik Değişkenlerin Doğrudan Yabancı Yatırımlar Üzerine Etkisi: Türkiye Ekonomisi Açısından Değerlendirme

rekabette yer almaktadır. Bu nedenle DYY girişi Türkiye'nin ekonomik büyümesi ile ilgili politikalarda özellikle vurgulanmakta ve çeşitli teşviklerle desteklenmektedir. Türkiye'nin uluslararası şirketler için bir üretim ve yönetim üssü haline getirilmesi hedefine yönelik önemli adımlarda ilki 2003 yılında yürürlüğe giren Doğrudan Yabanc1 Yatırımlar Kanunudur. Sonrasında 2006 yılından itibaren uygulanan yatırım teşvik düzenlemeleri ve 2007 yılında Başbakanlık Yatırım Destek ve Tanıtım Ajansı'nın faaliyete başlaması da bu alanda atılan önemli adımlar arasında yer alır. Ayrıca 2012 yılında kabul edilen yeni Türk Ticaret Kanunuyla beraber Avrupa Birliği mevzuatına uyum artırılmıştır (Yatırım Ofisi, 2021).

Bu bağlamda, sunulan çalışmanın amacı, Türkiye'de 1980 sonrası dışa açılma sürecinden sonra anlamlı düzeylere ulaşmaya başlayan ve günümüzde cazibesi her geçen gün artan DYY'lerin ülkeye girişlerinde çeşitli makroekonomik değişkenlerin etkilerinin analiz edilmesidir. Çalışmada öncelikle makroekonomik değişkenlerin DYY'ler üzerindeki etkisinin daha iyi anlaşılması amacıyla yabancı sermaye kavramı teorik olarak ele alınmaktadır. Sonrasında ulusal ve yabancı literatürde konuya ilişkin yer alan çalışmalardan bazıları irdelenmiştir. Ardından, seçilen makroekonomik değişkenlerin DYY'ler üzerindeki etkileri 1980-2020 dönemi için Eşbütünleşme Testi, Granger Nedensellik Testi ve Etki-Tepki Analizi ile test edilmiştir. Son olarak ampirik analizden elde edilen bulgulara yer verilerek bulgular ışığında değerlendirmeler yapılmıştır.

\section{Teorik Çerçeve}

\section{A. Doğrudan Yabancı Yatırım Kavramı}

DYY, uzun vadeli bir ilişkiyi içeren ve doğrudan yabancı yatırımcınınkinden farklı bir ekonomide yerleşik bir işletmenin veya kuruluşun ekonomide kalııı menfaatini ve kontrolünü yansıtan bir yatırım olarak tanımlanmaktadır (Francis, 2010: 31) IMF ve OECD tanımlarına göre ise, doğrudan yabancı yatırım, ülke ekonomilerindeki yerleşik bir kuruluşun (doğrudan yatırımcı) başka ülke ekonomisinde yerleşik bir işletmede (doğrudan yatırım işletmesi) kalııı bir menfaat elde etme amacını ifade etmektedir (Duce ve España, 2003: 2). Söz konusu tanımlar DYY yatırımcının diğer ekonomide ikamet eden işletmenin yönetimi üzerinde önemli bir etki uyguladığı anlamına gelmektedir. Bu tür yatırımlar, ticari kuruluşların yanı sıra bireyler tarafindan da gerçekleştirilebilmektedir.

DYY akışları, bir doğrudan yabancı yatırımcı tarafından bir işletmeye sağlanan sermayeyi veya bir doğrudan yabancı yatırımcı tarafindan bir yatııım kuruluşundan alınan sermayeyi kapsamaktadır. Öz sermaye, yeniden yatırılan kazançlar ve şirket içi krediler olmak üzere DYY'nin üç bileşeni söz konusudur (UNCTAD, 2007: 245).

Birçok gelişmekte olan ülkenin DYY'yi ekonomik kalkınma stratejilerinde önemli bir unsur olarak görmesi nedeniyle son otuz yılda, DYY akışları tüm dünyada hızla artmaktadır (Adams, 2009: 179). Tablo 1'de 2015-2020 yilları arasında dünyada, OECD, $A B$ ve G20 ülkelerinde DYY'lerin bölgelere olan akışı yer almaktadır. Genel olarak DYY akışlarında 2018 yılına kadar artış söz konusu iken, 2019 yılında genel toplamda ve bölgelere göre DYY akışlarında azalma görülmektedir. 2020 yılının ilk iki çeyreğinde ise ciddi bir DYY gerilemesi göze çarpmaktadır. Bunun nedeni COVID-19 salgınının 
2020'de DYY'de dramatik bir düşüşe neden olmasıdır. Küresel DYY akışı, 2019'da 1,5 trilyon dolar iken 2020 yllında yüzde 35 azalarak 1 trilyon dolara gerilemiştir. Bu azalış küresel mali krizden sonra 2009 yılına ilişkin dip seviyesinin neredeyse yüzde 20 altındadır (UNCTAD, 2021).

Tablo 1: DYY’lerin Bölgelere Akışı (Milyon \$)

\begin{tabular}{|l|c|c|c|c|c|c|c|}
\hline & & & & & & \multicolumn{2}{|c|}{$\mathbf{2 0 2 0}$} \\
\cline { 6 - 9 } Bölgeler & $\mathbf{2 0 1 5}$ & $\mathbf{2 0 1 6}$ & $\mathbf{2 0 1 7}$ & $\mathbf{2 0 1 8}$ & $\mathbf{2 0 1 9}$ & $\begin{array}{c}\mathbf{1 .} \\
\text { Çeyrek }\end{array}$ & $\begin{array}{c}\mathbf{2 .} \\
\text { Çeyrek }\end{array}$ \\
\hline OECD & 1.271 .265 & 1.416 .217 & 989.277 & 1.049 .892 & 851.814 & 75.426 & 52.813 \\
\hline $\begin{array}{l}\text { Avrupa } \\
\text { Birliği } \\
(\mathbf{A B})\end{array}$ & 581.059 & 674.875 & 418.891 & 645.262 & 408.025 & -2.199 & 120.392 \\
\hline $\begin{array}{l}\text { G-20 } \\
\text { Ülkeleri }\end{array}$ & 1.133 .797 & 1.288 .519 & 993.571 & 1.031 .489 & 930.367 & 174.767 & 71.057 \\
\hline $\begin{array}{l}\text { Dünya } \\
\text { Toplamı }\end{array}$ & 2.102 .398 & 2.124 .006 & 1.721 .578 & 1.784 .809 & 1.527 .683 & 203.722 & 159.998 \\
\hline
\end{tabular}

Kaynak: OECD, (2020)

\section{B. Makroekonomik Değişkenlerin Doğrudan Yabancı Yatırımlara Etkisi}

Ekonomik büyüme, döviz kuru, enflasyon işgücü maliyeti, hükümet istikrarı gibi makroekonomik değişkenlerin bir ülkeye giren doğrudan yabancı yatırımlar üzerinde belirleyici etkileri söz konusudur (Enu vd. 2013: 332). Dolayısıyla makroekonomik değiş̧kenler ile DYY arasındaki ilişki ele alınırken her bir makro değişken ile arasındaki ilişkinin varlığı ve yönünün altında yatan nedenleriyle birlikte değerlendirilmesi önem arz etmektedir (Sdahzad ve Al-Swidi, 2013: 272-273).

En temel makroekonomik değişkenlerden biri olan büyüme oranı, yabancı yatırımcıların yatırım kararları almalarında önemli bir etkiye sahiptir. Bu nedenle de büyüme oranının DYY girişleri üzerindeki etkisi ve/veya DYY girişlerinin büyüme üzerindeki etkisi literatürdeki araştırmaların ana odağı olmaktadır. MartinezZarzoso'nun (2003) ev sahibi ülkedeki yüksek büyüme düzeylerinin, yatırımcıların güven düzeyini artıran yüksek bir üretim düzeyine işaret ettiğini ifade etmektedir. Başka bir ifadeyle, ev sahibi ülkelerde ekonomik ve politik güven ne kadar yüksek ise, DYY girişleri o kadar yüksektir.

Yine enflasyon oranı, bir ülkenin fiyat istikrarını sağlama konusundaki başarısını yansıtmaktadır. Dolayısıyla enflasyon oranı, DYY girişlerini etkilemede çok önemli bir faktör olarak kabul edilmektedir. Genel olarak, ülkenin ekonomik istikrarsızlığını ifade eden yüksek enflasyon oranları, daha düşük DYY girişleriyle ilişkilidir (Alshamsi ve Azam, 2015; Çeviş ve Camurdan, 2007).

Diğer bir makro değişken olan ihracat, ülkenin ihracata dayalı büyümesinin ve ödemeler dengesindeki iyileşmenin bir göstergesi ve döviz kurunu dengeleyen bir faktör olarak kabul edilmektedir. Literatürde, ülkelerin ihracat hacminin DYY girişlerini çekme 
Makroekonomik Değişkenlerin Doğrudan Yabancı Yatırımlar Üzerine Etkisi: Türkiye Ekonomisi Açısından Değerlendirme

eğiliminde olduğu belirtilmektedir. İhracatın DYY'ler üzerindeki etkisini inceleyen Sultan (2013), DYY'nin ev sahibi ülkelerin küresel, bölgesel ve yerel pazarlardaki müşterilere erişimini kolaylaştırarak ihracatı teşvik ettiğini ortaya koymaktadır. Ek olarak, ev sahibi ülkelerin bazen ABD ve Çin örneklerinde olduğu gibi, yurtdışndaki bağlı kuruluşlarından yapılan ihracatlara olumlu muamele için kendi ülkelerindeki çok uluslu şirketlerin lobi faaliyetlerinden de yararlanmaları söz konusudur.

Bir ülkenin ithalatı hem ilk yatırım hem de işletme aşamalarında DYY'yi etkileyebilmektedir. İlk yatırım aşamasında, ekipmanlar, makineler, kurulum tesisleri ve uzmanların ithalatı, ithalat dengesinin artmasına sebep olmaktadır. DYY şirketlerinin, ev sahibi ülkede hemen bulunmayan sermaye ve ara mal ve hizmetleri ithal etme eğilimleri yüksektir. Yatırımın ilerleyen aşamalarında; girdi niteliği, çıktı türü, verimlilik yayılımı ve endüstrideki diğer rol oyuncularla olan ilişki türü, ithalatın bir ülkeye giren DYY'ler üzerindeki etkisinin yönünü belirlemektedir. İthalat yerel hammaddeleri ve diğer üretim girdileri ile ilgili ise, DYY'ler üzerinde olumsuz etkisi olmayabilir. Aksine, DYY'ler hammadde, insan becerisi ve diğer maddi olmayan varlıklarda ithal girdilere dayanıyorsa, ithalatın olumlu yönde etkilenmesi beklenmektedir (Jayakumar vd. 2014: 55). Başka bir ifadeyle, ithalatın artması, DYY'ler ile ilgili ise olumlu etki yaratırken, ithalatın azalarak yurtiçi hammadde ürünlerin kullanımı DYY girişlerinin artmasına neden olması beklenmektedir (Çelik vd., 2020: 370).

Bir ülkenin ödemeler dengesinin pozitif yönde olması DYY girişlerinin artmasına neden olacaktır. Çünkü bir ülkenin ödemeler dengesi beyannamesinin sermaye ve finans hesabı altında DYY girişleri rapor edilmektedir ve DYY girişleri ödemeler dengesi üzerinde doğrudan etkilidir. Dolayısıyla, ödemeler dengesi tablosunun sermaye ve mali hesabındaki fazla/açığı belirlemede DYY girişleri önemli bir rol oynamaktadır (Hossain, 2008: 4). Ödemeler dengesinde, cari açığı olan ülkelerin cari açığı azaltmak için ilk akla gelen çözüm 1980'li yıllardan sonra dünya genelinde dolaşım miktarı büyük derecede artan DDY'lerdir. Cari açık bir ülkeye DYY'lerin gelmesi, ödemeler dengesi üzerinde pozitif etkiler yaratacağı öngörülmektedir. Çünkü, ülkeye gelen yatırımların döviz cinsinden olması, ödemeler dengesi üzerinde olumlu etkiler oluşturmaktadır (Saygin, 2021: 428).

Bunlara ek olarak, dalgalanan döviz kurları, uluslararası ticaret ve yatırım kararlarını zorlaştırmaktadır, çünkü oynaklık döviz kuru riskini artırmaktadır. Döviz kuru riski, döviz kurundaki değişiklik nedeniyle para kaybetme potansiyelini ifade etmektedir. Döviz kuru ile DYY girişleri arasındaki bağlantıyı araştıran çeşitli ampirik çalışmalar, döviz kuru oynaklığının uzun vadeli üretim maliyetlerini ciddi şekilde etkilediğini ortaya koymaktadır (Meftah ve Nassour, 2019: 196).

\section{Türkiye'de DYY'nin Değerlendirilmesi}

Türkiye'de yabancı sermaye ile ilgili faaliyetlere 1954 yılında kabul edilen 6224 sayılı yasa ile resmi olarak başlanılmıştır. Söz konusu yasa, 1980'li yıllarda meydana gelen liberalleşme politikaları ile desteklenerek, 2003 yllında 4875 sayılı yasa ile "Doğrudan Yabancı Yatırımlar" yasası yürürlüğe girmiştir. Bu yasanın yürürlüğe girmesi ile DYY'ler artarak çeşitlenmiş̧ir (Ak ve Zengin, 2020: 98). 
Son 10 y1ldaki DYY'ler değerlendirildiğinde, gayrimenkul sektörü hariç, 2019 yılında 5,6 milyar dolarla son 10 yılın en düşük DYY girişi gerçekleşmiştir. DYY girişi 1999-2009 yılları arası dikkate alındığında 2009 yılında 19 milyar 937 milyon dolar ile en yüksek seviyesini görmüştür. 2015 y1lından sonra ise DYY girişlerinde düşüş görülmektedir. 2015 yılında, 12,2 milyar dolar olan DYY, 2018 yılında 7 milyar dolar civarlarında gerçekleşmiştir. Sektörler itibariyle DYY girişinin 2000-2020 yılları arasındaki seyri Şekil 1'de yer almaktadır (Aktaş, 2020).

Şekil 1. Sektörler İtibariyle 2000-2020 Döneminde Türkiye'de DYY

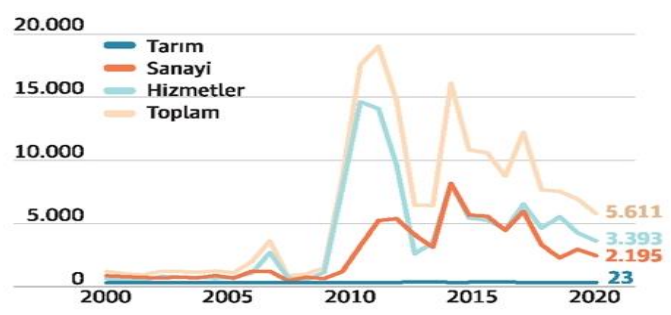

Kaynak: Aktaş, (2020).

Şekil 1'de görüldüğü üzere hem toplamda hem de sanayi ve hizmetler sektörü alanında yapılan DYY girişleri 2000-2009 yılları arasında durgun bir seyir izlerken 2009 yılından itibaren özellikle hizmetler sektöründe önemli bir artış yaşanmıştır. 2011 yılından sonra ise sanayi ve hizmetler sektöründe ve toplamda düşüş görülen DYY sonrasına inişli çıkışlı bir seyir izlemiştir. Dikkat çeken hususlardan biri de tarım sektöründe DYY'lerin yok denecek kadar az olması ve söz konusu dönemde hiçbir artış yaşanmamasıdır. 2020 yılında ise toplamda, DYY girişi 5.611 milyar dolar olmuştur.

Son 10 yıllık süreçte DYY istatistiklerinin yer aldığı Tablo 2'ye göre Türkiye'de DYY'ler son beş yılda \%54 gerilediği görülmektedir. 2020 yılında COVID salgını ile Hazine iç borçlanma kâğıtlarına olan ilgide rekor seviyelere düşmüştür. 2020 yılının Ocak-Mayıs döneminde DYY'ler, 2019 yılının Ocak-Mayıs dönemine göre \%28 düşerek 2.600 milyar dolar olarak gerçekleşmiştir. Bu bağlamda Şekil 2'de Ağustos 2017 ile Haziran 2020 dönemleri arasında DYY çıkışlarını ifade etmek için toplam devlet iç borçlanma senetleri ile yabancıların payı gösterilmektedir. Şekil 2'ye göre, Ağustos 2017 yılında devlet iç borçlanma senedi içinde yabancıların payı 34 milyar dolar iken, bu rakam Haziran 2020'de 7 milyar dolara kadar düşmüştür. Devlet İç Borçlanma Senedi satışları ise Haziran 2020 yılında 167 milyar dolardır.

Tablo 2. Türkiye'de 2009-2020 Döneminde DYY (Milyar \$)

\begin{tabular}{|c|c|c|c|}
\hline Yıllar & DYY Girişi & Yıl & DYY Girişi \\
\hline $\mathbf{2 0 0 9}$ & 7,032 & $\mathbf{2 0 1 5}$ & 14,167 \\
\hline $\mathbf{2 0 1 0}$ & 7,617 & $\mathbf{2 0 1 6}$ & 10,791 \\
\hline $\mathbf{2 0 1 1}$ & 13,812 & $\mathbf{2 0 1 7}$ & 8,398 \\
\hline $\mathbf{2 0 1 2}$ & 9,638 & $\mathbf{2 0 1 8}$ & 9,374 \\
\hline
\end{tabular}


Makroekonomik Değişkenlerin Doğrudan Yabancı Yatırımlar Üzerine Etkisi: Türkiye Ekonomisi Açısından Değerlendirme

\begin{tabular}{|l|l|l|l|}
\hline $\mathbf{2 0 1 3}$ & 9,927 & $\mathbf{2 0 1 9}$ & 5,507 \\
\hline $\mathbf{2 0 1 4}$ & 6,287 & $\mathbf{2 0 2 0}^{*}$ & 2,600 \\
\hline
\end{tabular}

Kaynak: TCMB, (2020) ve T.C. Hazine ve Maliye Bakanliğg (2020).

*Ocak-Mayıs dönemi.

Özet olarak, DYY girişlerinin düşüş yaşandığı bu zaman diliminde, Türkiye'deki makroekonomik değişkenlerle DYY arasındaki ilişkinin araştırılması önem kazanmaktadır. Özellikle döviz kurundaki dalgalanmalar, ekonomik büyümedeki gerileme gibi birçok faktörün DYY girişlerini olumsuz etkilediği görülmektedir. Bu nedenle DYY girişlerinin artması için Türkiye'nin öncelikle piyasalarda sürdürülebilir bir güven ortamı oluşturması önemlidir (Nur ve Dilber, 2017: 17).

Şekil 2. DYY Çıkışı (Milyar Dolar)

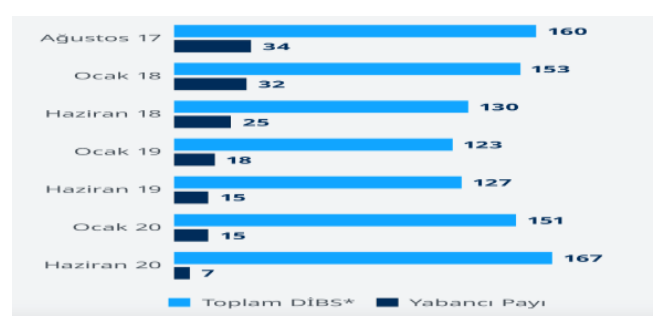

Kaynak: Duran, (2020).

* DIBS: Devlet İç Borçlanma Senedi

\section{Literatür Taraması}

\section{A. Yerel Çalışmalar}

DYY'ler ile makroekonomik değişkenler arasındaki ilişki ülkelere ve seçilen döneme göre farklılık göstermektedir. Türkiye üzerine yapılan çalışmalar incelendiğinde, genellikle ampirik analize dayanan çalışmaların ağırlıkta olduğu bulgulara göre makroekonomik değişkenlerden döviz kuru istikrarsızlı̆̆ının DYY girişlerini olumsuz etkileyen önemli bir faktör olduğu görülmektedir.

Koyuncu (2010) çalışmasında 1990-2009 dönemi için gerçekleştirdiği Yapısal Vektör Otoregresyon Analizi ile Türkiye'deki bazı makroekonomik değişkenlerin (GSYH, enflasyon, cari denge) DYY üzerindeki etkilerini araştırmıştır. Çalışmanın sonucunda ise, DYY'ler üzerinde en etkili faktörün piyasa hacmi olduğu tespit edilmiştir. Ayrıca, piyasa hacmini temsil eden GSYH ile DYY arasında uzun dönemli nedensellik ilişkisi olduğu görülmüştür. Özcan ve Ari (2010) ise ampirik araştırmalarında 1994-2006 döneminde $27 \mathrm{OECD}^{1}$ ülkesi için DYY'yi etkileyen faktörleri dinamik panel veri

\footnotetext{
${ }^{1}$ Almanya, Amerika Birleşik Devletleri, Avustralya, Avusturya, Belçika, Birleşik Krallık, Çek Cumhuriyeti, Danimarka, Estonya, Finlandiya, Fransa, Güney Kore, Hollanda, İrlanda, İspanya,
} 
yöntemiyle analiz etmişlerdir. Çalışmanın sonunda GSYH büyüme hızı, altyapı ve enflasyonun DYY'yi olumlu etkilediği görülürken; ticarete açıklığın ve cari hesap dengesinin DYY ile olumsuz bir ilişkisi olduğu tespit edilmiştir.

Diğer bir çalışmada Acaravcı ve Bostan (2011), 1992Q1-2007Q1 dönemi için ARDL eşbütünleşme testi ve bir dönem gecikmeli hata düzeltme terimi ile güçlendirilmiş Granger nedensellik modellerini kullanarak makroekonomik değişkenlerin DYY'ler üzerindeki etkilerini araştırmışlardır. Sonuçlar, doğrudan yabancı yatııımlar ile uzun vadede seçilmiş ekonomik büyüme gibi makroekonomik değişkenler arasında önemli bir ilişki olduğunu göstermektedir. Elde edilen bulgulara göre GSYH ve yerli yatırımlardaki artış, uzun vadede DYY'lerin artmasına neden olurken, doğrudan yabancı yatırımlardaki artış, kısa vadede ekonomik büyümenin artmasına yol açmaktadır.

Çiftçi ve Yıldız (2015) ise, Türkiye ekonomisine doğrudan yabancı yatırım akışlarını etkileyebilecek faktörleri, ilgili teorik yaklaşımlar çerçevesinde 1974-2012 dönemi verilerini kullanarak ampirik olarak analiz etmeyi amaçlamışlardır. Bulgular uzun dönemde GSYH, reel döviz kuru ve finansal gelişme değişkenlerinin doğrudan yabancı yatırımları olumlu etkilediğini, dış ticaret açığı ve dış borcun etkilerinin ise Özcan ve Ari (2010)'da olduğu gibi olumsuz olduğunu göstermektedir. Yine Cambazoğlu ve Güneş (2016) Türkiye'deki döviz kuru ile DYY girişleri arasında eşbütünleşme ilişkisi olduğu sonucuna varmışlardır. Ayrıca Kiyota ve Urata (2004: 1501) ev sahibi ülkenin para birimindeki değer kaybının DYY'yi çektiğini ve döviz kurundaki yüksek oynaklı̆̆ın DYY'yi caydırdığını ifade etmektedir.

Makroekonomik unsurlara ilave olarak kurumsal unsurların da etkisini irdeleyen çalışmalardan biri Yorulmaz vd. (2018)'dir. Çalışmada, makroekonomik, sosyal ve kurumsal değişkenlerin DYY üzerindeki etkisi analiz edilirken ekonometrik bir bakış açısı yerine çok değişkenli istatistiksel yöntemler kullanılmıştır. Dünya Bankası'nın 2014 veri setine dayanan araştırma OECD, Orta Doğu ve Latin Amerika ülkeleri olmak üzere üç ülke grubunu içermektedir. Çalışmanın ilk aşamasında birimler değişken olarak alınmış ve çeşitli makroekonomik, sosyal ve kurumsal değişkenler çok boyutlu bir ölçeklendirme tekniği kullanılarak üç ülke grubu dikkate alınarak incelenmiştir. İkinci aşamada homojen ülke grupları kümeleme analizi ile belirlenmiştir. Elde edilen bulgulara göre Ortadoğu ve Latin Amerika ülkeleri için DYY'yi etkileyen değişkenler kurumsal değişkenlerdir, yani siyasi istikrar, yolsuzluk seviyesi ve demokrasidir. Türkiye ve Kore ise OECD ülkeleri ile aynı kümede yer almaktadır.

Erdal (2019)'un amac1, Türkiye'deki sektörel DYY ve makroekonomik değişkenler arasındaki ilişkiyi ampirik olarak analiz etmektir. DYY girişlerinin özellikleri dikkate alınarak, reel döviz kuru, reel GSYH, ekonominin dişa açıklı̆g 1 ve reel faiz oranı makroekonomik değişkenler olarak seçilmiştir. Ampirik sonuçlar, ekonominin uluslararası pazarlara açıklı̆ğının Türkiye'ye DYY girişlerinde önemli bir değişken olduğunu göstermektedir. Ayrıca, reel kurun çok etkili olmasa da bazı sektörlerde olumlu, bazı sektörlerde ise olumsuz etkilere sahip olduğu görülmüştür. Reel GSYH'nın

İsveç, İsviçre, İsrail, İtalya, İzlanda, Japonya, Kanada, Lüksemburg, Macaristan Meksika, Norveç, Polonya, Portekiz, Slovakya, Slovenya, Şili, Türkiye, Yeni Zelanda ve Yunanistan. 
Makroekonomik Değişkenlerin Doğrudan Yabancı Yatırımlar Üzerine Etkisi: Türkiye Ekonomisi Açısından Değerlendirme

ise tarım ve üç alt sektör üzerinde olumlu etkileri olduğu tespit edilmiştir. Reel faiz oranının toplam DYY, finans ve sigorta faaliyetleri ile toplam DYY içinde en yüksek paya sahip bankacılık sektörleri üzerinde olumlu etkilere yol açtığı sonucuna ulaşılmıştır.

Tablo 3. Yerel Literatür Taraması

\begin{tabular}{|c|c|c|c|c|c|}
\hline S.No & $\begin{array}{l}\text { Yazar } \\
\text { /Tarih }\end{array}$ & $\begin{array}{l}\text { Ülke/Ülkeler } \\
\text { \&Ele Alınan } \\
\text { Dönemler }\end{array}$ & Değişkenler & $\begin{array}{c}\text { Analiz } \\
\text { Yöntemi }\end{array}$ & Çalışma Bulguları \\
\hline 1 & Erdal (2019) & $\begin{array}{l}\text { Türkiye } \\
\text { 2005-2016 }\end{array}$ & $\begin{array}{l}\text { DYY, Reel döviz kuru, } \\
\text { Reel GSYH, Dışa } \\
\text { Açıklık, Reel faiz oranı }\end{array}$ & $\begin{array}{l}\text { Eşbütünleşme } \\
\text { Analizi }\end{array}$ & $\begin{array}{l}\text { Reel faiz } \\
\text { oranının DYY, finans } \\
\text { ve sigorta faaliyetleri } \\
\text { ile toplam DYY } \\
\text { içinde en yüksek } \\
\text { paya sahip bankacılık } \\
\text { sektörleri üzerinde } \\
\text { olumlu etkisi vardır. }\end{array}$ \\
\hline 2 & $\begin{array}{l}\text { Yorulmaz, } \\
\text { vd. (2018) }\end{array}$ & $\begin{array}{l}\text { Ortadoğu } \\
\text { OECD, } \\
\text { Latin } \\
\text { Amerika } \\
\text { Ülkeleri, } \\
\text { Türkiye } \\
2014\end{array}$ & \begin{tabular}{lr}
\multicolumn{1}{c}{ DYY, } & Dışa \\
açıklık, & Enflasyon, \\
GSMH, & Yolsuzluk \\
Demokrasi & ve Hesap \\
verebilirlik & indeksi, \\
Enerji kullanımi, Politik \\
istikrar göstergeleri
\end{tabular} & $\begin{array}{l}\text { Çok Boyutlu } \\
\text { Ölçekleme } \\
\text { Yöntemi }\end{array}$ & $\begin{array}{l}\text { Siyasi istikrar, } \\
\text { yolsuzluk seviyesi ve } \\
\text { demokrasi gibi } \\
\text { kurumsal değişkenler } \\
\text { DYY'yi } \\
\text { etkilemektedir. }\end{array}$ \\
\hline 3 & $\begin{array}{l}\text { Kaya, vd. } \\
\text { (2017) }\end{array}$ & $\begin{array}{l}\text { Gelişmekte } \\
\text { Olan } 20 \\
\text { Ülke(Türkiye } \\
\text { Dahil) } \\
\text { 1997-2012 }\end{array}$ & $\begin{array}{l}\text { DYY, Kredi notu, } \\
\text { Risk primi }\end{array}$ & $\begin{array}{l}\text { Panel Veri } \\
\text { Analizi }\end{array}$ & $\begin{array}{l}\text { Kredi notları ve } \\
\text { risk primi ile temsil } \\
\text { edilen ülke riski } \\
\text { faktörleri, gelişmekte } \\
\text { olan ülkeler için } \\
\text { DYY ür üzerinde } \\
\text { pozitif } \\
\text { sahiptir. etkiye }\end{array}$ \\
\hline 4 & $\begin{array}{l}\text { Çiftçi ve } \\
\text { Y1ldız (2015) }\end{array}$ & $\begin{array}{l}\text { Türkiye } \\
\text { 1974-2012 }\end{array}$ & \begin{tabular}{l}
\multicolumn{2}{c}{ DYY, GSYH, D1ş } \\
ticaret açığı, Döviz \\
kuru, \\
gelişmişlik, Dinansal \\
yükü borç
\end{tabular} & $\begin{array}{l}\text { ARDL Sınır } \\
\text { Testi }\end{array}$ & $\begin{array}{l}\text { Uzun vadede } \\
\text { GSYH, reel döviz } \\
\text { kuru ve finansal } \\
\text { gelişme değişkenleri } \\
\text { DYY'yi olumlu } \\
\text { etkilerken, diş ticaret } \\
\text { açığ ve diş borçlar } \\
\text { DYY'yi olumsuz } \\
\text { etkilemektedir. }\end{array}$ \\
\hline 5 & $\begin{array}{l}\text { Acaravc1 ve } \\
\text { Bostan } \\
(2011)\end{array}$ & $\begin{array}{l}\text { Türkiye } \\
\text { 1992-2007 }\end{array}$ & $\begin{array}{l}\text { DYY, } \\
\text { GSYH, Reel } \\
\text { indeksi, İhracat, İthalat }\end{array}$ & $\begin{array}{l}\text { ARDL Sınır } \\
\text { Testi }\end{array}$ & \begin{tabular}{l}
\multicolumn{1}{c}{ GSYH ve yerli } \\
yatırımlardaki artış, \\
uzun vadede \\
DYY'lerin artmasına \\
neden olurken, \\
DYY'lerdeki artış, \\
kısa vadede \\
ekonomik \\
büyümenin artmasına \\
neden olmaktadır.
\end{tabular} \\
\hline
\end{tabular}




\begin{tabular}{|c|c|c|c|c|c|}
\hline 6 & $\begin{array}{l}\text { Koyuncu } \\
\text { (2010) }\end{array}$ & $\begin{array}{l}\text { Türkiye } \\
\text { 1990-2009 }\end{array}$ & 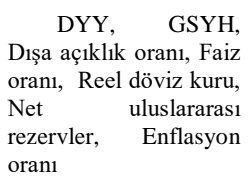 & $\begin{array}{l}\text { Yapısal Vektör } \\
\text { Otoregresyon } \\
\text { Analizi }\end{array}$ & $\begin{array}{l}\text { DYY miktarı; } \\
\text { GSYH, dişa açıklık } \\
\text { ve net uluslararası } \\
\text { rezervlerdeki } \\
\text { değişimlerden } \\
\text { etkilenmektedir. }\end{array}$ \\
\hline 7 & $\begin{array}{l}\text { Özcan ve } \\
\text { Ar1 } \\
\text { (2010) }\end{array}$ & $\begin{array}{l}27 \text { OECD } \\
\text { Ülkesi } \\
1994-2006\end{array}$ & $\begin{array}{l}\quad \text { DYY, GSYH, } \\
\text { Enflasyon, Dişa açıklık, } \\
\text { Altyapı düzeyi, Cari } \\
\text { açık }\end{array}$ & $\begin{array}{l}\text { Panel Veri } \\
\text { Analizi }\end{array}$ & $\begin{array}{l}\text { GSYH büyüme } \\
\text { hızı, altyap1 ve } \\
\text { enflasyonun DYY'yi } \\
\text { olumlu etkilerken diş } \\
\text { ticaret açığ1 ve cari } \\
\text { hesap dengesinin } \\
\text { DYY üzerindeki } \\
\text { etkisi olumsuzdur. }\end{array}$ \\
\hline
\end{tabular}

\section{B. Uluslararası Çalıșmalar}

Uluslararası çalışmalarda DYY ile makroekonomik değişkenler arasındaki ilişki analiz edilirken, analizde kullanılan makroekonomik değişkenlerin kullanılacak model çerçevesinde belirlendiği görülmektedir. Genel olarak modele değişken olarak alınan makroekonomik değişkenlerin enflasyon, faiz oranı ve döviz kuru olduğu görülmektedir.

Okafor (2012) çalışmasında, makroekonomik değişkenlerin Nijerya'daki sermaye hareketi üzerindeki etkisine odaklanmış ve En Küçük Kareler (OLS) yöntemi ile analiz gerçekleştirmiştir. Bulgular, reel GSYH, faiz oranı ve reel döviz kurunun Nijerya'daki doğrudan yabancı yatırımın temel belirleyicileri olduğunu göstermektedir. Sonuç, makroekonomik değişkenlerin DYY girişi için kritik olduğunu göstermektedir. Bu nedenle, politika yapıcılar, Nijerya'daki doğrudan yabancı yatırımın akışını ve faydalarını teşvik etmek için makroekonomik ortamı iyileştirmeye çalışmalıdır.

Diğer yandan Shahzad ve Al-Swidi (2013), Pakistan'daki makroekonomik değişkenler ile DYY girişleri arasındaki ilişkilerde siyasi istikrarın 1lımlı rolünü incelenmişlerdir. Çalışmanın sonuçları, Pakistan'daki DYY girişleri üzerinde GSYH büyüme oranı, ihracat, ithalat ve ödemeler dengesinin olumlu ve önemli etkileri olduğunu doğrulamıştır. Öte yandan, ülkedeki DYY girişlerinin belirlenmesinde enflasyon oranını önemli olmadığı sonucuna varılmıştır. Bununla birlikte, politik istikrarın ılımlı etkisi hesaba katıldığında, GSYH büyüme oranı ve ödemeler dengesi, DYY girişlerinin önemli bir belirleyicisi olma eğilimindedir.

Asaad (2014)'ün amacı ise Irak'ta DYY üzerinde üç makroekonomik değişkenin (enflasyon oranı, faiz oranı ve döviz kuru) etkisi 2004-2011 dönemi için çoklu regresyon yöntemi ile analiz etmektir. Çalışma sonuçları Irak'ta DYY üzerinde enflasyon ve faiz oranının anlamlı bir etkiye sahip değilken döviz kurunun negatif ve anlamlı bir etkinin varlığını göstermiştir. Dolayısıyla Irak hükümetinin ekonomik kalkınma ve yeniden yapılanma sürecinde daha fazla DYY çekmek amacıyla döviz kurunu sabitleyerek etkin para politikası oluşturmaya odaklanmıştır. 
Makroekonomik Değişkenlerin Doğrudan Yabancı Yatırımlar Üzerine Etkisi: Türkiye Ekonomisi Açısından Değerlendirme

DYY ile altı makroekonomik faktörler (döviz kuru, enflasyon, faiz oranı, ticaret açıklığı, piyasa büyüklüğü ve S\&P CNX 500 Hisse Endeksi) arasındaki ilişkiyi ele alan ve Asaad (2014)'ün aksi yönde bir sonuç elde eden çalışmalardan biri Tripathi vd. (2015)'e aittir. Çalışmanın ampirik analizinde Johansen Eşbütünleşme Testinden faydalanılmıştır. Sonuçlar, DYY ile döviz kuru hariç tüm makroekonomik değişkenler arasında önemli bir korelasyon olduğunu göstermektedir. Yine döviz kuru hariç tüm makroekonomik değişkenlerin DYY girişlerini önemli ölçüde etkilediği tespit edilmiş̧ir.

Asamoah vd. (2016) çalışmalarında 1996'dan 2011'e kadar Sahra Altı Afrika bölgesindeki 40 ülkede kurumsal kalitenin makroekonomik oynaklık ve DYY arasındaki ilişkiyi GARCH modeli ile incelemişlerdir. Elde edilen bulgulara göre makroekonomik belirsizliğin DYY akışını olumsuz etkilediği, kurumsal kaliteye ilişkin diğer kontrol değiş̧kenlerin ise DYY akışını artırdığı tespit edilmiştir. Diğer yandan kurumsal kalite ve makroekonomik belirsizlik arasındaki etkileşim, ekonomik belirsizliğin DYY akışı üzerinde yarattığı ilk olumsuz etkiyi azaltmaktadır.

Yine Ndubuisi (2017) makroekonomik değişkenlerin (ekonomik büyüme, döviz kuru, enflasyon ve petrol fiyatı) 1981-2014 döneminde Nijerya'daki DYY'ler üzerindeki etkisini Vektör Hata Düzeltme Modeli (VECM) ile incelenmiştir. Bulgulara göre, DYY ile reel GSYH arasında uzun vadeli tek yönlü bir nedensellik ilişkisi varken, kısa vadede nedensellik ilişkisi söz konusu değildir. Diğer yandan DYY ve döviz kuru arasında çift yönlü nedensellik varken; kısa vadede ise nedensel ilişkiye rastlanmamışıır. Kısa dönemde tüketici fiyat endeksi ile temsil edilen enflasyon oranından DYY'ye doğru kayda değer tek yönlü bir nedensellik söz konusu iken uzun vadede DYY ile petrol fiyatı arasında çift yönlü nedensellik tespit edilmiştir.

Oloyede ve Kolapo (2018) ise, Nijerya'da 1986-2016 dönemi için DYY'nin makroekonomik değişkenlere duyarlılığını En Küçük Kareler (OLS) yöntemi ile araştırmışlardır. Çalışmada GSYH, işsizlik oranı, enflasyon oranı, kamu harcamaları, döviz kuru, faiz oranı, nüfus ve dışa açılık bağımsız değişkenler için temsilciler olmuştur. Bulgular, enflasyon oranı, nüfus ve ticarete açıklığın DYY üzerinde önemli pozitif etkiye sahip olduğunu, ekonomik büyümenin ise olumsuz ama önemli bir etkiye sahip olduğunu ortaya koymaktadır. Diğer taraftan işsizlik, döviz kuru ve faiz oranları kısa vadede Nijerya'da DYY girişleri üzerinde olumsuz ve önemsiz bir etki yaratmaktadır. Bu nedenle, Nijerya'ya DYY girişi ekonomik büyüme, enflasyon, nüfus ve ticarete açıklıktaki değişikliklere duyarlıdır.

Lawson vd. (2019) ise gelişmekte olan ülkelerde DYY akışlarını çekmede seçici hükümet politikaları ve yatııım anlaşmalarının etkinliğini ele almaktadır. Çalışma kapsamında kullanılan değişkenler; altyapı istatistikleri, işgücü maliyeti, yıllık GSYH büyüme oranı, reel efektif döviz kuru ve vergi teşvikleri gibi ekonomik değişkenlerin DYY girişleri üzerindeki etkisi Gana için 1989-2018 dönemleri araliginda zaman serisi modeli yönetimi kullanılarak incelenmektedir. Ayrıca, analiz sonucunda DYY girişlerindeki yapısal kırılmalarda farklılık söz konusudur. 
Güncel çalışmalardan biri olan Canh vd. (2020) çalışmalarında, 2003-2013 döneminde Küresel Ekonomi Politikası Belirsizlik Endeksi kapsamındaki ülkeler ${ }^{2}$ için yurtiçi ekonomik belirsizlik ve dünya belirsizliğinin net DYY girişleri üzerindeki etkileri Doğrusal Panel Veri yöntemi ile araştırılmışlardır. Elde edilen bulgulardan birincisi, yurtiçi ekonomik belirsizliğinin büyüme hızı ve DYY girişlerini olumsuz etkilemesidir. İkinci olarak, 143 ülkenin ekonomik ve politika belirsizlikleri, ev sahibi ülkeye DYY girişleri üzerinde olumlu bir etkiye sahiptir. Bulgular, iç ekonomik belirsizliğin DYY girişleri üzerinde olumsuz bir etkiye sahip olmasına rağmen; küresel (dünya) ekonomik belirsizlikteki bir artışın ülkeye DYY girişlerini artırabileceğine işaret etmektedir.

Tablo 4. Uluslararası Çalışmalar

\begin{tabular}{|c|c|c|c|c|c|}
\hline S.No & $\begin{array}{l}\text { Yazar } \\
\text { /Tarih }\end{array}$ & $\begin{array}{l}\text { Ülke/Ülkele } \\
\text { r \&Ele } \\
\text { Alınan } \\
\text { Dönemler }\end{array}$ & Değişkenler & $\begin{array}{c}\text { Analiz } \\
\text { Yöntemi }\end{array}$ & Çalışma Bulguları \\
\hline 1 & $\begin{array}{l}\text { Canh, vd. } \\
\text { (2020) }\end{array}$ & $\begin{array}{l}\text { Küresel } \\
\text { Ekonomik } \\
\text { Belirsizlik } \\
\text { Endeksi } \\
\text { Kapsamındaki } \\
\text { Ülkeler } \\
\qquad 2003-2013\end{array}$ & \begin{tabular}{lr}
\multicolumn{1}{c}{ DYY, } & Reel \\
GSYIH & büyümesi, \\
Enflasyon & oranı, Brüt \\
sermaye, & Beşeri \\
sermaye, & $\mathrm{CO}_{2}$ \\
emisyonu, Reel döviz & kuru,
\end{tabular} & $\begin{array}{l}\text { Doğrusal Panel } \\
\text { Veri Analizi }\end{array}$ & 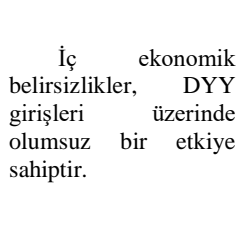 \\
\hline 2 & $\begin{array}{l}\text { Lawson } \\
\text { vd. (2019) }\end{array}$ & $\begin{array}{c}\text { Gana } \\
\text { 1989-2018 }\end{array}$ & $\begin{array}{l}\quad \text { DYY, İşgücü } \\
\text { maliyeti, Yıllık GSYİH } \\
\text { büyümesi, Reel efektif } \\
\text { döviz kuru, }\end{array}$ & $\begin{array}{c}\text { Zaman } \\
\text { Serisi Analizi }\end{array}$ & \begin{tabular}{l}
\multicolumn{1}{c}{ Analiz } \\
sonucunda, DYY \\
girişleri, $\quad$ yapisal \\
kirllma dönemlerinde \\
farklıllk \\
göstermektedir.
\end{tabular} \\
\hline 3 & $\begin{array}{l}\text { Oloyede } \\
\text { ve Kolapo } \\
\text { (2018) }\end{array}$ & Nijerya & $\begin{array}{l}\text { DYY, Enflasyon } \\
\text { oranı, Nüfus, Dişa } \\
\text { açıklık, İşsizlik, Döviz } \\
\text { kuru, Faiz oranı }\end{array}$ & $\begin{array}{r}\text { En Küçük } \\
\text { Kareler (OLS) } \\
\text { Yöntemi }\end{array}$ & $\begin{array}{l}\text { Enflasyon, nüfus } \\
\text { ve dışa açıklığın DYY } \\
\text { üzerinde pozitif etkisi } \\
\text { vardır. Diğer taraftan, } \\
\text { işsizlik, döviz kuru ve } \\
\text { faiz oranları kıs } \\
\text { vadede DYY girişlerini } \\
\text { olumsuz } \\
\text { etkilemektedir. }\end{array}$ \\
\hline 4 & $\begin{array}{l}\text { Ndubuisi } \\
\text { (2017) }\end{array}$ & $\begin{array}{c}\text { Nijerya } \\
1981-2014\end{array}$ & $\begin{array}{l}\text { DYY, Ekonomik } \\
\text { büyüme, Döviz kuru, } \\
\text { TÜFE, Petrol fiyatları }\end{array}$ & $\begin{array}{l}\text { Vektör Hata } \\
\text { Düzeltme } \\
\text { Modeli } \\
\text { (VECM) }\end{array}$ & $\begin{array}{l}\text { DYY ile reel } \\
\text { GSYİH arasında tek } \\
\text { yönlü bir nedensellik } \\
\text { vardır. DYY ve döviz } \\
\text { kuru arasında ise çift } \\
\text { yönlü nedensellik } \\
\text { bulunmaktadır. }\end{array}$ \\
\hline
\end{tabular}

${ }^{2}$ Avustralya, Brezilya, Kanada, Şili, Çin, Fransa, Almanya, Yunanistan, Hindistan, İrlanda, İtalya, Japonya, Meksika, Hollanda, Rusya, Güney Kore, İspanya, İsveç, Birleşik Krallık ve Amerika Birleşik Devletleri 
Makroekonomik Değişkenlerin Doğrudan Yabancı Yatırımlar Üzerine Etkisi: Türkiye Ekonomisi Açısından Değerlendirme

\begin{tabular}{|c|c|c|c|c|c|}
\hline 5 & $\begin{array}{l}\text { Asamoah, } \\
\text { vd. } \\
\quad{ }^{(2016}\end{array}$ & $\begin{array}{l}\text { Sahra Altı } \\
\text { Afrika } \\
\text { Bölgesindeki } \\
\text { Ülkeler } \\
\qquad 1996-2011\end{array}$ & $\begin{array}{l}\text { DYY, Döviz kuru } \\
\text { oynaklığ1, Dış ticaret, } \\
\text { Ekonomik büyüme }\end{array}$ & $\begin{array}{l}\text { GARCH } \\
\text { Modeli }\end{array}$ & \begin{tabular}{l}
\multicolumn{1}{c}{ Makroekonomik } \\
belirsizlik DYY akışını \\
olumsuz \\
etkilemektedir.
\end{tabular} \\
\hline 6 & $\begin{array}{l}\text { Tripathi, } \\
\text { vd (2015) }\end{array}$ & $\begin{array}{l}\text { Hindistan } \\
\text { 1997-2011 }\end{array}$ & \begin{tabular}{lr}
\multicolumn{1}{c}{ DYY, } & Döviz \\
kuru, Enflasyon oranı, & \\
Faiz oranı, & Dışa \\
açıklık, & Piyasa \\
büyüklüğü, S\&P CNX \\
500 Hisse Endeksi \\
(karlılık)
\end{tabular} & $\begin{array}{l}\text { Johansen } \\
\text { Eşbütünleşme } \\
\text { Testi }\end{array}$ & \begin{tabular}{l}
\multicolumn{2}{c}{ DYY ve döviz } \\
kuru hariç tüm \\
makroekonomik \\
değişkenler arasında \\
önemli bir korelasyon \\
bulunmuştur.
\end{tabular} \\
\hline 7 & $\begin{array}{l}\text { Asaad } \\
(2014)\end{array}$ & $\begin{array}{c}\text { Irak } \\
2004-2011\end{array}$ & \begin{tabular}{l}
\multicolumn{2}{r}{ DYY, Enflasyon } \\
oranı, Faiz \\
Döviz kuru
\end{tabular} & $\begin{array}{l}\text { Çoklu } \\
\text { Regresyon } \\
\text { Yöntemi }\end{array}$ & 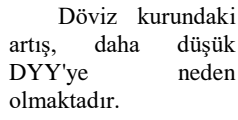 \\
\hline 8 & $\begin{array}{l}\text { Shahzad } \\
\text { ve Kaid } \\
\text { Al-Swidi } \\
\text { (2013) }\end{array}$ & $\begin{array}{c}\text { Pakistan } \\
\text { 1991-2011 }\end{array}$ & $\begin{array}{l}\text { DYY, GSYİH, } \\
\text { Cari açı, } \\
\text { İhracat, } \\
\text { Ithalat, Enflasyon oranı }\end{array}$ & $\begin{array}{l}\text { Regresyon } \\
\text { Analizi }\end{array}$ & $\begin{array}{l}\text { Pakistan'daki } \\
\text { DYY girişleri üzerinde } \\
\text { GSYİH büyüme oranı, } \\
\text { ihracat, ithalat ve } \\
\text { ödemeler dengesinin } \\
\text { olumlu etkisi vardır. } \\
\text { Öte yandan, DYY } \\
\text { girişlerinde enflasyon } \\
\text { oranı etkisizdir. }\end{array}$ \\
\hline 9 & $\begin{array}{l}\text { Okafor } \\
(2012)\end{array}$ & $\begin{array}{c}\text { Nijerya } \\
1970-2009\end{array}$ & $\begin{array}{l}\text { DYY, GSYİH, } \\
\text { Enflasyon oran1, Faiz } \\
\text { oranı, Döviz kuru ve } \\
\text { İhracat }\end{array}$ & $\begin{array}{l}\text { En Küçük } \\
\text { Kareler (OLS) } \\
\text { Yöntemi }\end{array}$ & $\begin{array}{l}\text { Makroekonomik } \\
\text { değişkenlerin DYY } \\
\text { girişi için kritik olduğu } \\
\text { tespit edilmiştir. }\end{array}$ \\
\hline 10 & $\begin{array}{l}\text { Musa ve } \\
\text { Ibrahim } \\
(2010)\end{array}$ & $\begin{array}{l}\text { MENA } \\
\text { Bölgesi, } \\
\text { 2006-2013 }\end{array}$ & $\begin{array}{l}\text { DYY, döviz kuru } \\
\text { ve enflasyon oranı }\end{array}$ & $\begin{array}{l}\text { Johansen } \\
\text { Eşbütünleşme } \\
\text { Testi }\end{array}$ & \begin{tabular}{lrr}
\multicolumn{2}{c}{ DYY'nin } & hisse \\
senedi & piyasasının \\
gelişimi & üzerinde \\
olumlu etki & vardır. \\
Ancak bu & etki \\
önemsizdir. &
\end{tabular} \\
\hline
\end{tabular}

\section{Türkiye Üzerine Uygulama}

\section{A. Çalışmanın Amacı ve Veri Seti}

Küreselleşme sonucunda ülkelerin orta ve uzun vadede sermaye ve teknoloji gelişimi için DYY'lere ihtiyaçları kaçınılmazdır. DYY'lerin ülkelere girişinin artırılması yönünde izlenecek politikalar kapsamında makroekonomik değişkenlerin DYY üzerindeki etkilerinin varlığının ve yönünün araştırılması yol gösterici nitelikte olacaktır. Dolayısıyla çalışmada, teorik altyapı ve beraberinde yerel ve uluslararası literatürden de faydalanılarak belirlenen temel makroekonomik değişkenlerin DYY üzerindeki etkilerinin ampirik olarak ortaya konulması amaçlanmaktadır. 
Çalışmada, makroekonomik değişkenlerinden ekonomik büyüme (GSYH), ihracat, ithalat, enflasyon, işsizlik ve cari açık bağımsız değişkenleri oluştururken, DYY bağımlı değişken olarak modele dahil edilmiştir. 1980-2020 dönemi yıllık verilerini kapsayan veri seti Türkiye Cumhuriyeti Merkez Bankası (TCMB), Türkiye İstatistik Kurumu (TÜIKK) ve Dünya Bankası (World Bank) web sitelerinden derlenmiştir. Analizde kullanılan değişkenler ile ilgili bilgiler Tablo 5'te verilmektedir. Analizden önce DYY değişkeni de dahil bütün değişkenlerin logaritmik değerleri alınarak analizde kullanılmıştır. Veriler Eviews 11 software programı vasıtasıyla analiz edilmiştir. Türkiye ekonomisi için temel makroekonomik değişkenler ile DYY arasındaki ilişkinin araştırılmasında aşağıdaki model kullanılmıştır:

$$
\begin{aligned}
& \quad D Y Y_{t}=\theta_{1}+\theta_{2} \mathrm{GSYH}_{t}+\theta_{3} \dot{\mathrm{I}}_{\mathrm{HT}}+\theta_{4} \dot{\mathrm{I}}_{\mathrm{TL}}+\theta_{5} \mathrm{CA}_{t}+\theta_{6} \mathrm{ENF}_{t}+ \\
& \theta_{7} \mathrm{ISSS}_{t}+\varepsilon_{t}
\end{aligned}
$$

Tablo 5. Değişkenlere Ait Bilgiler

\begin{tabular}{|c|c|c|}
\hline Değişkenler & Kısaltmalar & Kaynak \\
\hline Doğrudan Yabancı Yatırım (Milyon \$) & DYY & Dünya Bankası \\
\hline Ekonomik Büyüme (Milyar \$-SAGP) & GSYH & Dünya Bankası \\
\hline İhracat (Milyon \$) & İHT & Dünya Bankası \\
\hline İthalat (Milyon \$) & İTL & Dünya Bankası \\
\hline Cari Açık (Milyon \$) & CA & TCMB \\
\hline Enflasyon (TÜFE \%) & ENF & Dünya Bankası \\
\hline İşsizlik (\%) & İŞS & TÜİK \\
\hline
\end{tabular}

Zaman serisi kapsamında ilk olarak veri setinin durağanlıklarının araştırılması amacıyla birim kok testi uygulanmıştır. Model konusunda ise değişkenler arasındaki uzun dönemli ilişki için literatürde yaygın olarak tercih edilen eşbütünleşme testi yaklaşımı yapılmıştır.

\section{B.Birim Kök Testi}

Zaman serilerinin analizinde kullanılan veriler belli bir zamanı temsil ettiği için değişkenler birim kök içermesi muhtemeldir. Bundan dolayı değişkenlerin durağan olup olmadıkları genişletilmiş Dickey-Fuller (ADF) testi ile araştırılmıştır (Mushtaq, 2011). Standart Augmented Dickey-Fuller (ADF) testi sıklıkla tercih edilen birim kök testlerinden bir tanesidir. Otokorelasyon sorununu çözmek için bağımlı değişkenin gecikmelerinin denkleme eklendiği ADF testi için regresyon formülleri aşağıdaki gibidir (Uğurlu, 2009). 
Makroekonomik Değişkenlerin Doğrudan Yabancı Yatırımlar Üzerine Etkisi: Türkiye Ekonomisi Açısından Değerlendirme

$$
\begin{aligned}
& \Delta Y_{t}=p Y_{t-1}+\sum_{i=1}^{k} \beta_{i} \Delta Y_{t-1}+\varepsilon_{t} \\
& \Delta Y_{t}=\alpha_{0}+p Y_{t-1}+\sum_{i=1}^{k} \beta_{i} \Delta Y_{t-1}+\varepsilon_{t}
\end{aligned}
$$

$$
\Delta Y_{t}=\alpha_{0}+\beta_{t}+p Y_{t-1}+\sum_{i=1}^{k} \beta_{i} \Delta Y_{t-1}+\varepsilon_{t}
$$

$\mathrm{Bu}$ bağlamda, $\mathrm{ADF}$ testi için kurulan hipotezler ise;

$H_{0}: p=0$;serilerde durağanlık söz konusu değildir ve serilerde birim kök bulunmaktadır.

$H_{a}: p<0$; seriler durağandır ve serilerde birim kök yoktur.

Değişkenlerin sabitli, sabit ve trendli, sabitsiz ve trendsiz ADF testi sonuçları Tablo

\begin{tabular}{|c|c|c|c|c|c|c|c|c|}
\hline \multicolumn{9}{|c|}{ I (0) } \\
\hline & & İŞS & CA & ENF & DYY & GSYH & İHT & İTL \\
\hline \multirow{2}{*}{ Sabitli } & t-istatistik & $-2,4554$ & $-3,5909$ & $-1,7361$ & $-1,7570$ & $-1,4395$ & $-2,0606$ & $-0,6766$ \\
\hline & p-de ğeri & 0,1338 & 0,0117 & 0,4047 & 0,3936 & 0,5531 & 0,2611 & 0,8403 \\
\hline \multirow{2}{*}{$\begin{array}{c}\text { Sabit- } \\
\text { Trendli }\end{array}$} & t-istatistik & $-3,7539$ & $-3,5993$ & $-4,1447$ & 3,1257 & 0,7453 & $-1,7148$ & $-2,4341$ \\
\hline & p-dĕgeri & 0,0302 & 0,0458 & 0,0130 & 1,0000 & 0,9995 & 0,7256 & 0,3565 \\
\hline \multirow{2}{*}{$\begin{array}{l}\text { Sabitsiz- } \\
\text { Trendsiz }\end{array}$} & t-istatistik & $-0,1366$ & $-3,2412$ & $-2,2701$ & 0,8667 & $-1,9366$ & 4,9124 & 1,0021 \\
\hline & p-dĕgeri & 0,6304 & 0,0020 & 0,0241 & 0,8917 & 0,0514 & 1,0000 & 0,9134 \\
\hline \multicolumn{9}{|c|}{ I (1) } \\
\hline & & $\Delta \mathbf{I S S S S}$ & $\Delta \mathrm{CA}$ & $\Delta \mathrm{ENF}$ & $\Delta D Y Y$ & $\Delta$ GSYH & $\Delta$ İHT & $\Delta \mathbf{I T L}$ \\
\hline \multirow{2}{*}{ Sabitli } & t-istatistik & $-5,8120$ & $-5,2277$ & $-8,6035$ & $-3,4962$ & 5,3232 & -6.2477 & $-9,0003$ \\
\hline & p-dĕgeri & 0,0000 & 0,0000 & 0,0000 & 0,0152 & 0,0000 & 0.0000 & 0,0000 \\
\hline \multirow{2}{*}{$\begin{array}{c}\text { Sabit- } \\
\text { Trendli }\end{array}$} & t-istatistik & $-5,7631$ & $-6,0786$ & $-8,3995$ & $-3,6409$ & 7,9952 & -6.1745 & $-8,8724$ \\
\hline & p-dĕgeri & 0,0002 & 0,0000 & 0,0000 & 0,0430 & 0,0000 & 0.0000 & 0,0000 \\
\hline \multirow{2}{*}{$\begin{array}{l}\text { Sabitsiz- } \\
\text { Trendsiz }\end{array}$} & t-istatistik & $-11,1946$ & $-6,1373$ & $-8,7710$ & $-2,6049$ & $-7,1418$ & $-4,4277$ & $-2,5798$ \\
\hline & p-değeri & 0,0000 & 0,0000 & 0,0000 & 0,0134 & 0,0000 & 0,0000 & 0,0115 \\
\hline
\end{tabular}
6'da sunulmaktadır.

Tablo 6. ADF Birim Kök Testi Bulguları

Tablo 6'ya göre değişkenlerden sadece cari açık değişkeni düzeyde durağan iken diğerleri düzeyde durağan değildir. Değişkenlerin birinci farkları alındığında tamamı durağan hale gelmektedir. Durağanlaşan değerler, yapılacak olan analizlerde kullanılmaktadır. 


\section{Johansen Eşbütünleşme Analizi}

Durağan hale gelen veriler arasında eşbütünleşme ilişki olup olmadığı Johansen eşbütünleşme analizi ile test edilmiştir (Ahking, 2002: 52). Bu amaç doğrultusunda çalışmadaki veriler için yapılan Johansen eşbütünleşme testi sonuçları aşağıda verilen Tablo 7'de sunulmaktadır.

Tablo 7'ye göre, $\% 5$ anlamlılık düzeyinde $r=0$ için Trace (iz) testi ve Max. Özdeğer testi istatistiksel değerlerinin tablo kritik değerlerinden büyük olması değişkenler arasında eşbütünleşme (uzun dönemli denge) vektörü olduğunu ifade etmektedir. Ayrıca, hem iz testi hem de maksimum özdeğer testi 0,05 düzeyinde 3 eşbütünleşme denklemi olduğunu göstermektedir. Başka bir ifadeyle, $\% 5$ anlamlılık seviyesinde eşbütünleşik üç adet vektör vardır. Bundan dolayı $\mathrm{H}_{0}$ (değişkenler arasında eşbütünleşme yoktur) hipotezi reddedilerek \%5 anlamlılık seviyesinde DYY ile makroekonomik değişkenler arasında uzun dönemli bir ilişki olduğu kabul edilmektedir.

Tablo 7. Johansen Eşbütünleşme Testi Bulguları

\begin{tabular}{|l|c|l|l|l|l|l|}
\hline $\mathbf{H}_{\mathbf{0}}$ & $\boldsymbol{\lambda}_{\text {trace }}$ & $\mathbf{\% 5} \mathbf{( 0 , 0 5 )}$ & $\mathbf{p - d e g ̆ e r i}$ & $\boldsymbol{\lambda}_{\max }$ & $\mathbf{\% 5}(\mathbf{0 , 0 5})$ & $\begin{array}{l}\mathbf{p}- \\
\mathbf{d e g ̆ e r i}\end{array}$ \\
\hline $\mathbf{r}=\mathbf{0}^{*}$ & 223,5855 & 169,5991 & 0,0000 & 67,98077 & 53,18784 & 0,0009 \\
\hline $\mathbf{r} \leq \mathbf{1}^{*}$ & 155,6047 & 134,6780 & 0,0016 & 48,96139 & 47,07897 & 0,0310 \\
\hline $\mathbf{r} \leq \mathbf{2}^{*}$ & 106,6433 & 103,8473 & 0,0322 & 42,07239 & 40,95680 & 0,0373 \\
\hline $\mathbf{r} \leq \mathbf{3}$ & 64,57095 & 76,97277 & 0,3016 & 23,79323 & 34,80587 & 0,5375 \\
\hline $\mathbf{r} \leq \mathbf{4}$ & 40,77771 & 54,07904 & 0,4319 & 18,76853 & 28,58808 & 0,5110 \\
\hline $\mathbf{r} \leq \mathbf{5}$ & 22,00918 & 35,19275 & 0,5949 & 9,576183 & 22,29962 & 0,8666 \\
\hline $\mathbf{r} \leq \mathbf{6}$ & 12,43300 & 20,26184 & 0,4108 & 8,974478 & 15,89210 & 0,4366 \\
\hline $\mathbf{r} \leq \mathbf{7}$ & 3,458521 & 9,164546 & 0,4987 & 3,458521 & 9,164546 & 0,4987 \\
\hline
\end{tabular}

Eşbütünleşmeyi güvenilir bir şekilde kontrol etmek için uygun gecikme uzunluğunu belirlemek çok önemlidir. Bu amaçla Akaike Bilgi Kriteri (AIC), Hannan Quinn Bilgi Kriteri (HQIC) ve Schwarz Bayesian Kriteri (SBC) kullanılmıştır. Lag seçim kriterleri aşağıda verilen Tablo 8'de sunulmaktadır.

Tablo 8. Gecikme Uzunluğu Seçim Kriterleri

\begin{tabular}{|r|r|r|l|l|l|l|}
\hline $\mathbf{L a g}$ & $\mathbf{L o g L}$ & $\mathbf{L R}$ & $\mathbf{F P E}$ & AIC & SBC & HQIC \\
\hline $\mathbf{0}$ & $-932,2586$ & NA & $4,29 \mathrm{e}+11$ & 49,48729 & 49,83205 & 49,60996 \\
\hline $\mathbf{1}$ & $-745,4827$ & $285,0790^{*}$ & $7,21 \mathrm{e}+08^{*}$ & 43,02541 & $46,12820^{*}$ & $44,12936^{*}$ \\
\hline $\mathbf{2}$ & $-682,8959$ & 69,17490 & $1,24 \mathrm{e}+09$ & 43,09978 & 48,96062 & 45,18502 \\
\hline $\mathbf{3}$ & $-590,0714$ & 63,51150 & $1,29 \mathrm{e}+09$ & $41,58271^{*}$ & 50,20158 & 44,64924 \\
\hline
\end{tabular}


Makroekonomik Değişkenlerin Doğrudan Yabancı Yatırımlar Üzerine Etkisi: Türkiye Ekonomisi Açısından Değerlendirme

Not: * kriter tarafından seçilen gecikme sırasını gösterir

LR: Sıralı Modifiye LR Test İstatistiği (Her Test \%5 Seviyesinde);FPE: Son T Hatası; AIC: Akaike Bilgi Kriteri; SBC: Schwarz Bilgi Kriteri; HQIC: HannanQuinn Bilgi Kriteri

Tablo 8'e göre, eşbütünleşmeyi test etmek için kullanılması gereken uygun gecikme uzunluğu VAR=1 olarak seçilmiştir. VAR modelinin hata terimlerinde otokorelasyon sorunu olup olmadığının araştırılması için Lagrange Çarpanı (LM) testi uygulanmıştır. LM testine göre istatistik değeri 100,91 ve p-değeri 0,0022 olarak belirlenmiştir. Elde edilen bulgular değişkenler arasında otokorelasyon sorununun olmadığını göstermektedir. VAR modelinin kararlılığını ve doğruluğunu sağlamak için AR köklerinin 1'den küçük olması gerekmektedir. Ayrıca, Granger nedenselliği tahmin etmeden önce gecikme uzunluğunu belirledikten sonra elde edilen VAR modelinde sürecin durağanlığının kontrol edilmesi için AR süreç grafiği çizilmiştir ve elde edilen AR karakteristik polinomunun ters kök grafiği Şekil 3'te yer almaktadır.

\section{Şekil 3. AR Süreç Grafiği}

Inverse Roots of AR Characteristic Polynomial

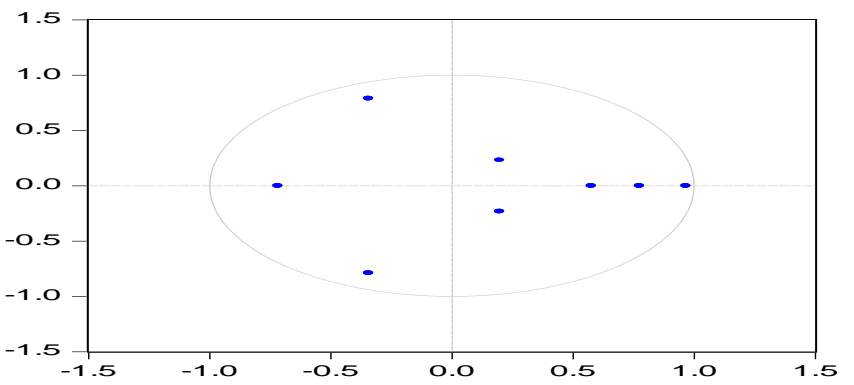

Şekil 3 'te görüldüğü gibi tüm ters köklerin birim çember içinde olduğu belirlenmiştir. Başka bir ifadeyle, bütün ters kökler 1 sınırlarındadır ve buna bağlı olarak VAR modelinin kararlılık koşulunu sağladığı görülmüştür. Bunlara ek olarak, regresyon modelinin gerekliliklerinden biri de gözlemlerin hata terimlerinin normal dağılmış olmasıdır. Çalışmada normalliğin testi amacıyla Cholesky (Lutkepohl) testi kullanılmıştır ve elde edilen bulgular Tablo 9'da sunulmaktadır.

Tablo 9. Cholesky VAR Normallik Test Sonuçları

\begin{tabular}{|c|c|c|c|c|}
\hline & Çarpıklık & Ki Kare & df & Olasılık (p Değeri) \\
\hline $\mathbf{1}$ & $-0,071749$ & 0,034320 & 1 & 0,8530 \\
\hline $\mathbf{2}$ & $-1,251911$ & 0,448574 & 1 & 0,6312 \\
\hline $\mathbf{3}$ & $-3,234754$ & 1,757754 & 1 & 0,2014 \\
\hline $\mathbf{4}$ & 0,448460 & 1,340777 & 1 & 0,2469 \\
\hline $\mathbf{5}$ & 0,981030 & 2,416131 & 1 & 0,0713 \\
\hline $\mathbf{6}$ & $-0,900331$ & 2,403974 & 1 & 0,0701 \\
\hline
\end{tabular}




\begin{tabular}{|c|c|c|c|c|}
\hline $\mathbf{7}$ & $-0,652431$ & 2,837775 & 1 & 0,0921 \\
\hline $\mathbf{8}$ & 0,446394 & 1,328453 & 1 & 0,2491 \\
\hline & Basıklık & Ki Kare & df & Olasılık (p Değeri) \\
\hline $\mathbf{1}$ & 2,541634 & 0,350165 & 1 & 0,5540 \\
\hline $\mathbf{2}$ & 8,770562 & 2,192897 & 1 & 0,0624 \\
\hline $\mathbf{3}$ & 18,32160 & 1,225524 & 1 & 0,2350 \\
\hline $\mathbf{4}$ & 3,480215 & 0,384343 & 1 & 0,5353 \\
\hline $\mathbf{5}$ & 5,239992 & 2,162603 & 1 & 0,0638 \\
\hline $\mathbf{6}$ & 5,282505 & 1,683047 & 1 & 0,2032 \\
\hline $\mathbf{7}$ & 2,969377 & 0,001563 & 1 & 0,9685 \\
\hline $\mathbf{8}$ & 2,590503 & 0,279479 & 1 & 0,5970 \\
\hline
\end{tabular}

Tablo 9'da görüldüğü üzere, Skewness ve Kurtosis istatistikleri ki-kare test istatistiklerinden büyük olduğundan artıkların normal olarak dağıldığı sonucuna ulaşılmıştır. Ek olarak aykırı değerlere karşı oldukça duyarlı olan Jarque-Bera testi uygulanmıştır. Seride çarpıklık olmadığı ve serinin üç basıklığa sahip olduğu ortak hipotezini test eden Jarque-Bera (1987) normallik testi asimptotik bir testtir. Elde edilen sonuca göre kalanların \%5 anlamlılık düzeyinde çok değişkenli normal olduğu hipotezi kabul edilmiştir. Bu sonuç, tahmin edilen VAR modelinin doğru bir şekilde belirlendiği anlamina gelmektedir.

Son olarak, VAR modeli için White Değişen Varyans testi yapılmıştır ve sonuçlar Tablo 10'da verilmektedir. Tablo 10'a göre değişen varyans testinin sonucu anlamlı olmadığından Granger nedensellik şartlarını sağlamaktadır.

Tablo 10. White Değişen Varyans Testi Sonuçları

\begin{tabular}{|c|c|c|}
\hline Ki Kare & Df & P değeri (olasılık) \\
\hline 597,1768 & 576 & 0,2624 \\
\hline
\end{tabular}

\section{Granger Nedensellik Analizi}

Ekonomik değişkenler arasında eşbütünleşme ilişkilerinin olabileceği yaygın olarak bilinmektedir. Engle ve Granger (1987) tarafından eşbütünleşmenin varlığını araştırmak için geliştirilen Granger nedensellik testi tahmine dayalı istatistiksel bir nedensellik kavramıdır (Salman ve Shukur, 2004: 493). Değişkenler arasındaki neden-sonuç ilişkisinin tespiti gayesiyle yapılan Granger nedensellik testine ilişkin bulgular aşağıda Tablo 11'de verilmektedir. Nedensellik analiz bulgularına göre, enflasyon ile DYY arasında çift yönlü nedensellik ilişkisi varken, ekonomik büyüme ve DYY arasında büyümeden DYY'ye olmak üzere tek yönlü bir nedensellik olduğu bulunmuştur. Diğer değişkenler ile DYY arasında ise herhangi bir nedensellik ilişkisi olmadığı görülmektedir. Diğer bir ifadeyle, DYY'lerin ülkeye girişinde işsizlik, cari açık, ihracat ve ithalat değişkenlerin çok etkili olmadığı söylenebilir. 
Makroekonomik Değişkenlerin Doğrudan Yabancı Yatırımlar Üzerine Etkisi: Türkiye Ekonomisi Açısından Değerlendirme

Tablo 11. Granger Nedensellik Analiz Bulgular

\begin{tabular}{|l|c|c|c|}
\hline \multicolumn{1}{|c|}{ Değişkenler } & Gecikme Değeri & F-istatistiği & p-değeri \\
\hline IŞS - DYY & 1 & 1,669936 & 0,1963 \\
\hline DYY - İŞS & 1 & 0,119742 & 0,7293 \\
\hline CA - DYY & 1 & 1,673941 & 0,1957 \\
\hline DYY - CA & 1 & 1,507517 & 0,2195 \\
\hline ENF ↔ DYY & 1 & 8,996616 & $\mathbf{0 , 0 0 2 7}$ \\
\hline DYY $\leftrightarrow$ ENF & 1 & 6,649865 & $\mathbf{0 , 0 3 6 0}$ \\
\hline GSYH $\rightarrow$ DYY & 1 & 8,520243 & $\mathbf{0 , 0 0 8 6}$ \\
\hline DYY - GSYH & 1 & 1,289229 & 0,5249 \\
\hline IHT - DYY & 1 & 1,365305 & 0,2426 \\
\hline DYY - İHT & 1 & 0,049925 & 0,8232 \\
\hline ITL - DYY & 1 & 0,649447 & 0,4203 \\
\hline DYY - İTL & 1 & 0,340591 & 0,8434 \\
\hline
\end{tabular}

\section{E. Etki Tepki Analizi}

Değişkenler arasındaki neden-sonuç ilişkileri tespit edildikten sonra değişkenlerin dışsaldan içsele doğru sıralaması, uzun vadede etki tepki analizi için önem arz etmektedir. Çalı̧̧ma kapsamında nedensellik analizine göre, nedensel ilişkinin tespit edildiği enflasyon ve ekonomik büyüme değişkenleri için etki-tepki analizi de yapılmıştır.

Şekil 4. GSYH ve Enflasyonun DYY Değişimlerine Verdiği Tepkiler

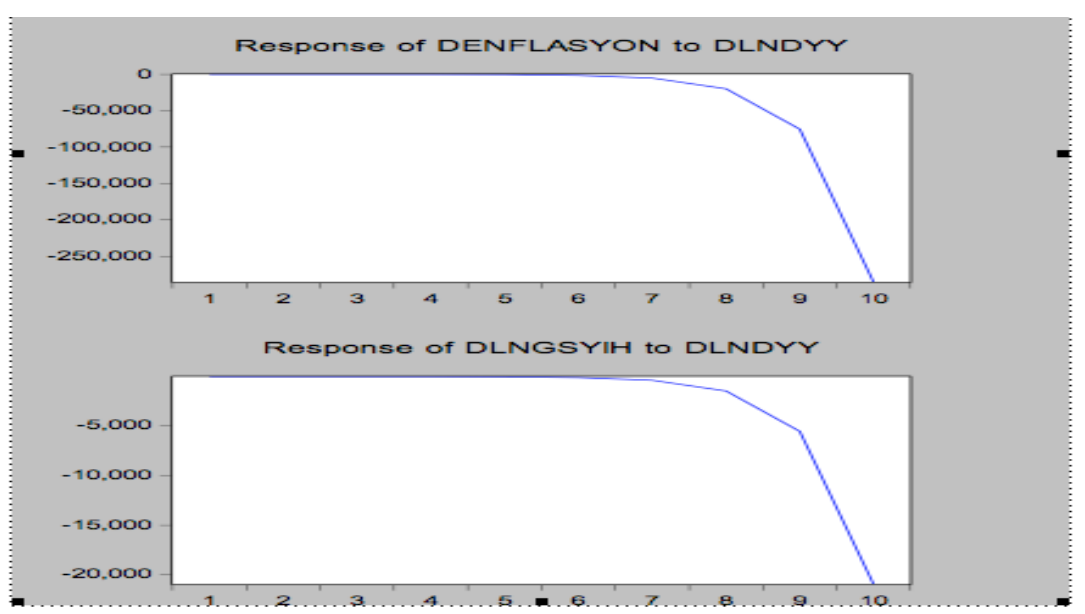

Etki-tepki analizinden elde edilen sonuçlar Şekil 4'te verilmiştir. Etki-tepki fonksiyonlarının zaman içinde sıfıra yakınsaması, tahmin edilen modelin kararlılığının 
bir göstergesidir. DYY'da meydana gelen bir şokun enflasyon ve GSYH üzerindeki etkileri her iki makro değişken içinde 10. dönemin sonunda sona ermektedir.

\section{Sonuc}

Ekonomik büyümenin önündeki en önemli engellerden biri de sermaye yetersizliğidir. Bundan dolayı, gelişmekte olan ülkeler büyüme ve kalkınmaları için ileri teknolojik yatırımlardan yararlanarak ülkenin refahını maksimum noktaya çıkarmak için DYY hareketlerini teşvik edici düzenlemeler yapmaktadır. Gelişmekte olan bir ülke konumundaki Türkiye, yabancı sermayenin ülkeye gelmesi için yoğun çaba göstermesine karşın yeterli düzeyde başarı sağlayamadığı görülmektedir. Bu bağlamda sunulan çalışmanın amacı makroekonomik değişkenlerden ekonomik büyüme, ithalat, ihracat, cari açık, enflasyon ve işsizliğin doğrudan yabancı yatıımlar üzerindeki etkilerinin 1980-2020 dönemi için Eşbütünleşme ve Granger Nedensellik Testi kullanılarak ortaya konulmasidır.

Çalışma kapsamında gerçekleştirilen eşbütünleşme analizi sonuçlarına göre, DYY ile ele alınan makroekonomik değişkenler arasında uzun dönemli ilişkili olduğu tespit edilmiştir. Değişkenler arasındaki neden-sonuç ilişkisinin araştırıldığı Granger Nedensellik testi sonuçlarına göre ise, DYY ile enflasyon arasında çift yönlü, ekonomik büyüme ile DYY arasında ise büyümeden DYY'ye doğru olmak üzere tek yönlü nedensellik ilişkisi tespit edilmiş̧ir. Buna karşsn modele dahil edilen diğer makro değiş̧kenlerle DYY arasında bir neden-sonuç ilişkisi söz konusu olmadığı belirlenmiş̧ir.

Başka bir ifadeyle, GSYH, döviz kuru, enflasyon oranı, dışa açıklık, net uluslararası rezervler ve faiz oranı gibi makroekonomik değişkenler, DYY'lerin ülkelere gelmesinde uzun dönemde etkili olmaktadır. Çalışmada elde edilen bulgulara göre ele alınan makroekonomik değiş̧enlerden enflasyon ve ekonomik büyüme değiş̧enleri ile DYY arasındaki ilişki anlamlı bulunmuştur. Dolayısıyla Türkiye ekonomisi için ele alınan dönemde ekonomik büyümedeki artışın, DYY akışlarını da hızlandıracağı sonucu ortaya çıkmıştır. İstikrarlı ve yüksek bir ekonomik büyüme hızı daha cazip kârlılık oranları sunması nedeniyle yatırımlar için avantajlı bir ortam oluşturmaktadır. Bu bulguyu destekleyen literatürde birçok çalışma (Ndubuisi, 2017; Çiftçi ve Yıldız, 2015; Koyuncu, 2010; Özcan ve Ari, 2010; Okafor, 2012; Shahzad ve Al-Swidi, 2013 ve Ndubuisi, 2017) mevcuttur.

Enflasyon oranı ile DYY girişleri arasındaki ilişkinin ise çift yönlü olduğu belirlenmiştir. Fiyat istikrarı ülkeye DYY girişlerini etkileyen önemli bir unsurdur. Elde edilen bu bulgu Alshamsi ve Azam (2015), Çeviş ve Camurdan (2007) ve Ndubuisi (2017)'nin çalı̧̧malarını destekler yöndedir. Diğer yandan aradaki ilişkinin çift yönlü olmasından ötürü DYY girişlerindeki artış fiyat istikrarının sağlanması açısından pozitif yönde etki yaratmaktadır. Düşük enflasyon seviyesinin doğrudan yabancı yatırımı teşvik etmesinin arkasında enflasyon düşük olduğunda, nominal faiz oranının ve bunun sonucunda sermaye maliyetinin düşük olması yatmaktadır.

Elde edilen bulgular ışı̆̆ında Türkiye'de DYY girişlerinin artmasında ekonomik büyüme süreci ve fiyat istikrarının önemli olduğu görülmektedir. Özellikle Kovid- 19 salgınından ötürü yüzde 15 azalarak 7,9 milyar dolara gerileyen Türkiye'ye DYY 
Makroekonomik Değişkenlerin Doğrudan Yabancı Yatırımlar Üzerine Etkisi: Türkiye Ekonomisi Açısından Değerlendirme

girişlerinin artırılması açısından makroekonomik istikrarın önemli olduğu görülmektedir. Diğer yandan gelişmekte olan ülke konumundan gelişmiş ülke konumuna geçiş sürecinde ekonomik büyüme beklentileri nedeniyle DYY'lerin ülkemize akış sürecinin hızlanması beklenmektedir. Uluslararası ticaret ve yatırımlar, ülkemizde ekonomik büyümenin vazgeçilmez motorları haline gelmiş̧ir ve sürdürülebilir kalkınma hedefleri açısından da temel uygulama araçları olmaya devam etmektedir. Dolayısıyla makroekonomik istikrarın sağlanmasında hükümetin destekleyici yöndeki politikalarına ihtiyaç duyulabilmektedir.

\section{Kaynaklar}

Acaravcı, A., \& Akyol, M. (2017). Türkiye'de doğrudan yabancı yatırımlar, dış ticaret ve ekonomik büyüme ilişkisi. Uluslararası Ekonomi ve Yenilik Dergisi, 3(1), 17-33.

Acaravc1, A., \& Bostan, F. (2011). Makroekonomik Değiş̧kenlerin Doğrudan Yabancı Yatırımlar Üzerine Etkileri: Türkiye Ekonomisi İçin Ampirik Bir Çalışma. Çag University Journal of Social Sciences, 8(2): 56-68.

Adams, S. (2009). Can foreign direct investment (FDI) help to promote growth in Africa?. African Journal of Business Management, 3(5), 178-183.

Ahking, F. W. (2002). Model mis-specification and Johansen's co-integration analysis: an application to the US money demand. Journal of Macroeconomics, 24(1), 51-66.

Aktaş, T. (2020). Doğrudan yabancı yatırımlar 15 yllın en düşük seviyesinde, https://www.dunya.com/kose-yazisi/dogrudan-yabanci-yatirimlar-15-yilin-endusuk-seviyesinde/478362, Erisim Tarihi: 14.11.2020.

Alshamsi, K. H., \& Azam, M. (2015). The impact of inflation and GDP per capita on foreign direct investment: the case of United Arab Emirates. Investment management and financial innovations, 12(3), 132-141.

Asaad, Z. (2014). The Economic determinants of foreign direct investment inward to Iraq for period (2004-2011).Journal of University of Duhok, 17(1), 1192-2017.

Asamoah, M. E., Adjasi, C. K., \& Alhassan, A. L. (2016). Macroeconomic uncertainty, foreign direct investment and institutional quality: Evidence from Sub-Saharan Africa. Economic Systems, 40(4), 612-621.

Aytekin, G. K. (2019). Doğrudan Yabancı Yatırımlar, Belirleyicileri ve Ekonomik Etkileri. Ufuk Üniversitesi Sosyal Bilimler Enstitüsü Dergisi, 15(8), 255-278.

Cambazoğlu, B., \& Sevcan, G. (2016). The Relationship between Foreign Exchange Rate and Foreign Direct Investment in Turkey. Economics, Management, and Financial Markets, 11(1), 284-293.

Canh, N. P., Binh, N. T., Thanh, S. D., \& Schinckus, C. (2020). Determinants of foreign direct investment inflows: The role of economic policy uncertainty. International Economics, 161, 159-172. 
Çelik, H., Yılmaz, H., \& Erdemli, M. (2020). Doğrudan Yabancı Yatırımların Dış Ticaret Üzerindeki Etkisi: G8 Ülkeleri İçin Ampirik Bir Uygulama. Finans Ekonomi ve Sosyal Araştırmalar Dergisi, 5(3), 369-376.

Çeviş, İ., \& Camurdan, B. (2007). The economic determinants of foreign direct investment in developing countries and transition economies. The Pakistan Development Review, 46(3), 285-299.

Çiftci, F., \& Yıldız, R. (2015). Doğrudan Yabancı Yatırımların Ekonomik Belirleyicileri: Türkiye Ekonomisi Üzerine Bir Zaman Serisi Analizi. Business \& Economics Research Journal, 6(4): 71-95.

Duce, M., \& España, B. D. (2003). Definitions of foreign direct investment (FDI): A methodological note. Banco de Espana.

Duran, A. E. (2020). "Türkiye yabancı yatırımcıya "güven" vermiyor", https://www.dw.com/tr/t\%C3\%BCrkiye-yabanc\%C4\%B1yat\%C4\%B1r\%C4\%B1mc\%C4\%B1ya-g\%C3\%BCven-vermiyor/a-54335209, Erisim Tarihi: 14.11.2020.

Enu, P., Havi, E. D. K., \& Attah-Obeng, P. (2013). Impact of macroeconomic factors on foreign direct investment in Ghana: A cointegration analysis. European Scientific Journal, 9(28): 331-348.

Erdal, B. (2019). Türkiye'ye Gelen Yabancı Doğrudan Yatırımları Uzun Dönemde Ve Kısa Dönemde Etkileyen Makroekonomik Değişkenler. Sosyal ve Beşerî Bilimler Dergisi, 11(2), 48-63.

Francis, S. (2010). Foreign Direct Investment Concepts: Implications for Negotiations. Economic and Political Weekly, 45(22), 31-36.

Göçer, I., Mercan, M., \& Peker, O. (2013). Ihracat, Dogrudan Yabanci Yatirimlar ve Issizlik: Türkiye Örnegi/Export, Foreign Direct Investment and Unemployment: The Case of Turkey. Business and Economics Research Journal, 4(1), 103-120.

Hossain, M. A. (2008). Impact of foreign direct investment on Bangladesh's balance of payments: Some policy implications. Policy Note, 805, 1-9.

Jayakumar, A., Kannan, L., \& Anbalagan, G. (2014). Impact of foreign direct investment, imports and exports. International Review of Research in Emerging Markets and the Global Economy (IRREM), 1(1), 51-58.

Kanlı, N. K., \& Aydoğuş, O. (2017). Ülke Risk Faktörlerinin Doğrudan Yabanc1 Yatırımlar Üzerindeki Belirleyici Etkisi. Ege Academic Review, 17(2): 179-190.

Kiyota, K., \& Urata, S. (2004). Exchange Rate, Exchange Rate Volatility and Foreign Direct Investment. The World Economy, 27(10), 1501-1536

Korkmaz, Ö., \& Daştan, B. (2020). Türkiye'de Doğrudan Yabancı Yatırımlar İle İşsizlik Oranı Arasındaki İlişki (2005-2019). Uluslararası Ekonomi Siyaset İnsan ve Toplum Bilimleri Dergisi, 3(4), 260-279. 
Makroekonomik Değişkenlerin Doğrudan Yabancı Yatırımlar Üzerine Etkisi: Türkiye Ekonomisi Açısından Değerlendirme

Koyuncu, F. T., (2010). Türkiye'de Seçilmiş Makroekonomik Değişkenlerin Doğrudan Yabancı Sermaye Yatırımları Üzerindeki Etkisinin Yapısal Var Analizi: 1990-2009 Dönemi. Ekonomi Bilimleri Dergisi, 2(1), 55-62.

Kurt, Ü (2018). Türkiye Ekonomisinde Ekonomik İstikrar, Tüketici Güveni Ve Doğrudan Yabancı Yatırımlar İlişkisinin ARDL Modeli ile Analizi. Turkish Studies, Economics, Finance and Politics, Volume 13/14, 307-320, DOI: http://dx.doi.org/10.7827/TurkishStudies.13462

Lawson, J., Du, K., \& Bentum-Micah, G. (2019). The Impact of Macroeconomic Variables, Investment Incentives and Government Agreements on FDI Inflows in Ghana. Journal of Economics and Business, 2(3):1038-1056.

Martínez-Zarzoso, I. (2011). The log of gravity revisited. Applied Economics, 45(3), 311-327.

Meftah, S., \& Nassour, A. (2019). Macroeconomic Variables and Foreign Direct Investment Inflows in Turkey. Signifikan: Jurnal Ilmu Ekonomi, 8(2), 195-206.

Musa, S. U., \& Ibrahim, M. (2010). Stock market development, foreign direct investment and macroeconomic stability: Evidence from Nigeria. World, 62, 258-264.

Mushtaq, R. (2011). Augmented dickey fuller test. SSRN Paper, HANGI SAYI, 1-19.

Ndubuisi, P. (2017). An analysis of the impact of macroeconomic variables and foreign direct investment in Nigeria: A VECM granger causality framework. Journal of Business and Economic Development, 2(3), 187-197.

Nur, H. B., \& Dilber, İ. (2017). Gelişmekte olan ülkelerde doğrudan yabancı yatırımları belirleyen temel unsurlar. Dokuz Eylül Üniversitesi İktisadi İdari Bilimler Fakültesi Dergisi, 32(2), 15-45.

Okafor, H. O. (2012). Do domestic macroeconomic variables matter for foreign direct investment inflow in Nigeria. Research journal of finance and accounting, 3(9), 5567.

Oloyede, J. A., \& Kolapo, F. T. (2018). Sensitivity of Foreign Direct Investment to Macroeconomic Variables in Nigeria. Advances in Social Sciences Research Journal, 5(7):409-427.

Özcan, B., \& Ari, A. (2010). Doğrudan Yabancı Yatırımların Belirleyicileri Üzerine Bir Analiz: OECD Örneği. Istanbul University Econometrics \& Statistics e-Journal, 12(1): 65-88.

Salman, A. K., \& Shukur, G. (2004). Testing for Granger causality between industrial output and CPI in the presence of regime shift. Journal of Economic Studies, 31(6), 492-499.

Saygın, S. Ü. (2021). Cari açık ve doğrudan yabancı yatırımlar arasındaki ilişki: MIST ülkeleri için ampirik bir analiz. Business \& Management Studies: An International Journal, 9(2), 426-438. 
Shahzad, A., \& Al-Swidi, A. K. (2013). Effect of macroeconomic variables on the FDI inflows: The moderating role of political stability: An evidence from Pakistan. Asian Social Science, 9(9), 270-280.

Sultan, Z. A. (2013). A causal relationship between FDI inflows and export: The case of India. Journal of Economics and Sustainable Development, 4(2), 1-9.

T.C. Hazine ve Maliye Bakanlığı (2020). Temel Ekonomik Göstergeler. https://ms.hmb.gov.tr/uploads/2020/06/temelekonomikgostergeler-1.pdf, Erisim Tarihi: 13.11.2020.

TCMB (2020). Uluslararasl Yatırım Pozisyonu, https://www.tcmb.gov.tr/wps/wcm/connect/cb23c98d-d9a5-465f-8c9c9f84b533aaf8/uyp.pdf?MOD=AJPERES\&CACHEID=ROOTWORKSPACEcb23c98d-d9a5-465f-8c9c-9f84b533aaf8-mRdu7rb, Erişim Tarihi: 13.11.2020.

T. C. Cumhurbaşkanlığı Yatırım Ofisi (2021). Türkiye’de Uluslararası Doğrudan Yatırımlar. https://www.invest.gov.tr/tr/sayfalar/home-page.aspx, Erişim Tarihi: 10.11.2021.

Tripathi, V., Seth, R., \& Bhandari, V. (2015). Foreign direct investment and macroeconomic factors: Evidence from the Indian economy. Asia-Pacific Journal of Management Research and Innovation, 11(1), 46-56.

Uğurlu, E. (2009). Durağanlı ve Birim Kök Sinamalarl. https://www.academia.edu/2402640/Dura\%C4\%9Fanl\%C4\%B1k_Birim_K\%C3\% B6k S\%C4\%B1namalar\%C4\%B1, Erişim Tarihi: 05.06.2021.

UNCTAD (United Nations Conference on Trade and Development) (2007), Definitions, https://unctad.org/system/files/official-document/wir2007p4_en.pdf, Erisim Tarihi: 13.11.2020.

UNCTAD (United Nations Conference on Trade and Development) (2021). World Investment Report. Investing in Sustainable Recovery. https://unctad.org/system/files/official-document/wir2021_en.pdf, Erisim Tarihi: 08.11.2021.

Yorulmaz, Ö., Yakut, S. G., \& Gacar, B. K. (2018). Doğrudan Yabancı Yatırımları Etkileyen Faktörlerin Çok Değişkenli İstatistiksel Yöntemler ile İncelenmesi. Uluslararası İnsan Çalışmaları Dergisi, 1(2), 63-73.

Wijeweera, A., Villano, R., \& Dollery, B. (2010). Economic growth and FDI inflows: A stochastic frontier analysis. The Journal of Developing Areas, 43(2), 143-158. 